\title{
William Ockham on the Scope and Limits of Consciousness
}

\author{
Susan Brower-Toland \\ Saint Louis University
}

\begin{abstract}
William Ockham (ca. 1287-1347) holds what nowadays would be characterized as a "higher-order perception" theory of consciousness. Historically speaking, one of the most persistent objections to this type of theory is the charge that it gives rise to an infinite regress in higher-order states. In this paper, I examine Ockham's efforts to respond to the regress problem, focusing in particular on his attempts to restrict the scope of consciousness so as to avoid it. In his earlier writings, Ockham holds that we are conscious only of those states to which we explicitly attend. This view, I go on to argue, is inadequate on both phenomenological and philosophical grounds. Interestingly, and perhaps for this very reason, in later works, Ockham goes on to develop an alternative explanation for his account of the limited scope of consciousness.
\end{abstract}

\section{Keywords}

Ockham - consciousness - intuitive cognition - medieval - higher-order perception attention

William Ockham (ca. 1287-1347) takes it as a datum of ordinary experience that we are conscious of a wide range of our subjective states. "Everyone," he says, "experiences in himself that he thinks, loves, rejoices, and grieves."1 Ockham

1 Guillelmus de Ockham, Ordinatio, Prologue, q. 1, a. 1, ed. G. Gál with S. Brown (OTh I), 28.15-16: “...quilibet experitur in se quod intelligit, diligit, delectatur, tristatur..." All references to Ockham's Latin texts are to his Opera Theologica (= OTh) (St. Bonaventure, N.Y., 1967-88). I use the following abbreviations in referring to particular works: Ord. = Ordinatio. Scriptum in Librum Primum Sententiarum; Rep. II = Reportatio. Quaestiones in Librum Secundum 
explains such consciousness by appeal to acts of inner awareness or inner perception. Indeed, as I've argued elsewhere, he holds what nowadays would be characterized as a "higher-order perception" theory of consciousness. ${ }^{2}$ Although Ockham is not the first to hold such a theory, he is, nevertheless, one of the first to develop and defend it in any systematic way. ${ }^{3}$

Among the most common objections raised against higher-order theories of consciousness is the charge that they give rise to an infinite regress in higherorder states. Indeed, the problem of regress is among the most persistent and longstanding objections to higher-order theories of consciousness. It is perhaps not surprising, therefore, that Ockham's opponents press just such an objection against his account of consciousness. Part of what motivates this objection among Ockham's contemporaries is the assumption that all mental states (or at least all occurrent mental states) are self-intimating and, hence, conscious. But, clearly, if consciousness is ubiquitous in this way, and a state's being conscious is a matter of its serving as the object for some higher-order state, then this higher-order state must likewise occur consciously and, thus, be targeted by a further higher-order state-and so on ad infinitum.

Ockham does sometimes say things that suggest a commitment to selfintimation (i.e., a commitment to the thesis that being in a given mental state is sufficient for awareness of that very state). Even so, his official position is that only some of our states occur consciously. Indeed, on his view, consciousness is restricted primarily to a proper subset of one's occurrent first-order states. Hence, no regress looms. Yet, even if restricting the scope of consciousness provides him a ready response to the regress objection, it also places on him the burden of justifying such restrictions. And meeting this burden proves challenging for Ockham. There are elements in his theory of perception that, when applied to higher-order perception, appear to entail that mental states are self-intimating — and, hence, that consciousness is ubiquitous. If this is

Sententiarum, ed. G. Gál and R. Wood (OTh V); Rep. III = Reportatio. Quaestiones in Librum Tertium Sententiarum, ed. F.E. Kelley and G.I. Etzkorn (OTh VI); Quaest. Var. = Quaestiones Variae, ed. G.I. Etzkorn, F.E. Kelley, and J.C. Wey (OTh VIII); Quodl. = Quodlibeta Septem, ed. J.C. Wey (OTh IX). Unless otherwise noted, translations are my own.

2 See S. Brower-Toland, 'Medieval Approaches to Consciousness: Ockham and Chatton', Philosophers Imprint 12.17 (2012), 1-29.

3 Ockham's account is, for example, clearly influenced by Scotus (and both thinkers draw inspiration from Augustine). Yet, Ockham goes much further than Scotus when it comes to developing and defending the view that consciousness owes to higher-order perception. For a brief discussion of Scotus's treatment of consciousness, see R. Cross, Duns Scotus's Theory of Cognition (Oxford, 2014), ch. 2. 
right, however, Ockham is (pace his claims to the contrary) vulnerable to the regress charge after all.

In this paper, I explore Ockham's response to the regress problem with the aim of understanding his account of both the scope and the limits of consciousness. My discussion divides into three parts. First, I offer a brief summary of his theory of consciousness as higher-order perception. Because I have defended this interpretation at length elsewhere, my presentation here is fairly succinct. Second, I consider the charge of infinite regress leveled against Ockham's theory of consciousness, focusing specifically on the way in which it is developed by one of his immediate successors-Walter Chatton. The regress objection is not original to Chatton, but his treatment of it proves especially important in shaping Ockham's thinking on the matter. Third and finally, I turn to Ockham's response to this objection. Here I focus particularly on Ockham's attempts to justify his claim about the limited scope of consciousness. Interestingly, his views appear to undergo some development. In earlier writings, he claims that we are conscious only of those states to which we explicitly attend. I go on to argue, however, that this line of response is inadequate on both phenomenological and philosophical grounds. It is, I suggest, perhaps for just this reason that Ockham, in his later works, offers an alternative explanation for his account of the limits of consciousness.

\section{Ockham's Theory of Consciousness}

Proponents of higher-order perception theories hold that consciousness occurs as a kind of inner-awareness, or higher-order perception, of one's own states. ${ }^{4}$ On this model, consciousness is (or entails) a kind of self-consciousness; it is perception of what occurs within oneself. A conscious state, then, is a state one is aware of being in.

4 Leading defenders of higher-order perception theories include D. Armstrong, A Materialist Theory of the Mind (London, 1968); W. Lycan, Consciousness and Experience (Cambridge, MA, 1996); idem, 'A Simple Argument for a Higher-Order Representation Theory of Consciousness', Analysis 61 (2001), 3-4; idem, 'The Superiority of HOP to HOT', in Higher-Order Theories of Consciousness: An Anthology, ed. R. Gennaro (Amsterdam, 2004). It may also have been the view of Locke, Kant, and other early modern inner-sense theorists - though recently the attribution of this theory to Locke has been challenged. See A. Coventry and U. Kriegel, 'Locke on Consciousness', History of Philosophy Quarterly 25 (2008), 221-242. 
To see that Ockham's account fits such a model we need to begin by situating his theory of consciousness vis-à-vis his theory of perception in general. ${ }^{5}$ Ockham's views about perception are developed in the context of his treatment of intuitive and abstractive cognition. Broadly speaking, we can think of the distinction between intuitive and abstractive cognition as one between perceptual and non-perceptual states - with intuitive cognition approximating our own (pre-theoretical) notion of perception. For Ockham, intuitive cognition is a type of cognition that provides immediate access to the world and grounds judgments regarding contingent, current, local matters of fact-i.e., how things stand right here and now. ${ }^{6}$ Indeed, Ockham distinguishes intuitive cognition precisely in terms of the two-fold role it plays in perceptual judgments. ${ }^{7}$ The first of these roles is, as it were, psychological in nature. According to Ockham, intuitive cognition of an object is such that, by virtue of it, "the intellect immediately judges that [the object] exists" and possesses certain attributes. Indeed, Ockham thinks that an intuitive cognition of an object is such that it automatically gives rise to judgments concerning its current exis-

5 A more detailed presentation and defense of this interpretation of Ockham's view can be found in Brower-Toland, 'Medieval Approaches to Consciousness', 2-9.

6 On Ockham's view, intuitive cognitions are caused only by objects in relevant proximityi.e., within causal reach of one's sensory faculties. Hence, barring supernatural intervention, intuitive cognition is restricted to entities within one's immediate environment. See note 21 below.

7 See Ord. Prol. q. 1, a. 1, ed. Gál and Brown (OTh I), 31.10-12: “... notitia intuitiva rei est talis notitia virtute cuius potest sciri utrum res sit vel non, ita quod si res sit, statim intellectus iudicat eam esse et evidenter cognoscit eam esse..." ("Intuitive cognition of a thing is cognition such that by virtue of it one can know whether a thing exists or does not exist so that, if the thing does exist, the intellect immediately (statim) judges that it exists and evidently cognizes that it exists."); 31.17-22: "Similiter, notitia intuitiva est talis quod quando aliquae res cognoscuntur quarum una inhaeret alteri vel una distat loco ab altera vel alio modo se habet ad alteram, statim virtute illius notitiae incomplexae illarum rerum scitur si res inhaeret vel non inhaeret, si distat vel non distat, et sic de aliis veritatibus contingentibus ..." ("Likewise, intuitive cognition is such that when [two or more] things are cognized, one of which inheres in another, or is spatially distant from another, or stands in some other relation to another, then, by virtue of this non-propositional cognition, one immediately (statim) knows whether the one thing inheres or not, is distant or not, and so on concerning other contingent truths."); 32.4-5: "Notitia autem abstractiva est illa virtute cuius de re contingente non potest sciri evidenter utrum sit vel non sit." "Abstractive cognition, on the other hand, is that cognition by virtue of which we cannot know concerning some contingent thing whether it exists or does not."); 32.10-11: "Similiter, per notitiam abstractivam nulla veritas contingens, maxime de praesenti, potest evidenter sciri." ("Thus, by means of an abstractive cognition we cannot evidently cognize any contingent truth-in particular, no truth relating to the present.") 
tence and contingent, perceptible characteristics. ${ }^{8}$ In addition, intuitive cognition plays a second, broadly epistemic role in relation to the judgments it occasions. Ockham claims that such judgments are uniquely secure, epistemically speaking. Such judgments constitute "evident knowledge" or "evident cognition" (where evidentness is a qualifier signaling privileged epistemic status). By contrast, abstractive cognition plays neither of these two roles. Indeed, Ockham introduces the label 'abstractive' for any state that fails to play one or more of the roles he associates with intuitive cognition.

Just as knowledge regarding our immediate external environment is grounded in intuitive cognition, the same holds true for knowledge regarding our own current, subjective states. Self-knowledge is, thus, a type of perceptual knowledge. Ockham defends this position by appeal to what he takes to be obvious phenomenological and epistemological parallels between perceptual knowledge and self-knowledge. "We experience these things in ourselves [namely, acts of thinking, desiring, etc.]," he says, "in just the way we experience sensible things." ${ }^{9}$ Thus, just as perceptual awareness of extra-mental objects is utterly immediate, so also is awareness of our own states. ${ }^{10}$ Again, Ockham takes our awareness of our states to be epistemically immediate in just the way ordinary perceptual awareness is. Thus, he claims that self-knowledge is, like ordinary perceptual knowledge, both evident and non-inferential in nature:

This is clear since this is evidently known to me: 'I am thinking' (ego intelligo). [...] The fact that it is evidently cognized requires intuitive cognition. [...] Given that there is no contingent truth from which 'I am thinking' follows necessarily ... it cannot be cognized evidently [by inference] from something prior. ${ }^{11}$

Thus, our awareness of our states functions in self-knowledge in a way analogous to that in which intuitive cognition functions vis-à-vis ordinary

8 Thus, if I intuitively cognize Socrates, this intuition will automatically give rise to a number of beliefs about him — say, beliefs to the effect that Socrates is right here, that he is pale, that he is standing to the left of me, and so on.

9 Ord. Prol. q. 1, a. 1, ed. Gál and Brown (OTh I), 41.6-7: “... ita experimur ista in nobis sicut quaecumque sensibilia."

10 Ockham holds that one of the distinguishing features of intuitive states in general is that they make their objects experientially present to us.

11 Ord. Prol. q. 1, a. 1, ed. Gál and Brown (OTh I), 40.5-6, 13-14, 16-17; 41.2-3: “... patet, quia haec est evidenter mihi nota 'ego intelligo'. [...] igitur ad hoc quod evidenter cognoscatur requiritur aliqua notitia intuitiva. [...] quia nulla est contingens ex qua necessario sequatur ista 'ego intelligo' [...] non potest evidenter cognosci per aliam priorem." 
perceptual judgments. In this regard, Ockham takes quite seriously the traditional Augustinian metaphors that represent self-knowledge as inner "vision" or a kind of "seeing" into one's own "mind" or "heart."12 He seems to think that Augustine's use of such metaphors lends authoritative weight to his account of consciousness as a kind of inner perception or intuition.

As the foregoing makes clear, on Ockham's view, consciousness is a matter of higher-order perception; indeed, his account of consciousness is just a higher-order iteration of his general theory of perception. To clarify the precise nature of the parallel between ordinary and inner-perception, consider the following diagram, which represents (very schematically) Ockham's account of the structure of perception and perceptual knowledge in general:

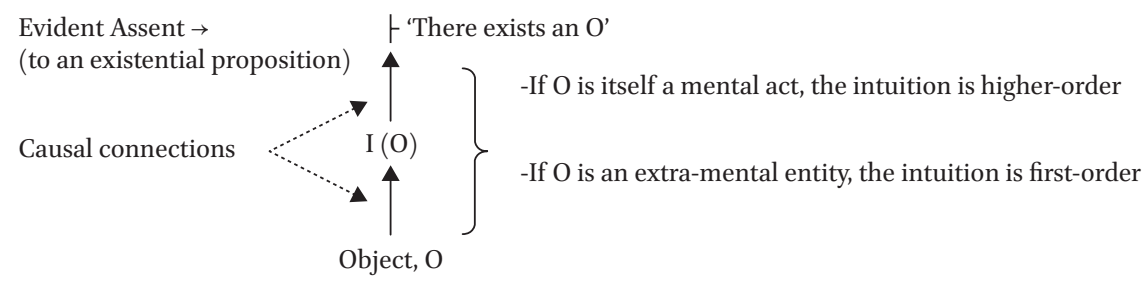

The General Structure of Perception

As the diagram shows, in ordinary cases, perception begins with some worldly object, $0 .{ }^{13}$ Under ordinary circumstances, moreover, the presence of the object brings about in the cognizer an act of intuitive cognition, $\mathrm{I}(\mathrm{O}) \cdot{ }^{14}$ This

12 See Ord. Prol. q. 1, a. 1, ed. Gál and Brown (OTh I), 29-30; 41-44.

13 The diagram and this summary involve some oversimplification. On Ockham's view, in the natural order, perception actually involves two acts of intuitive cognition: one at the level of the senses, another at the level of intellect. Thus, strictly speaking, perception of some object, $\mathrm{O}$, begins with a sensory intuitive awareness of $\mathrm{O}$, which in turn occasions an intellective intuitive cognition of $\mathrm{O}$. The act of intellective intuition then efficiently causes the formation (in the intellect) of one or more judgments regarding O. Ockham's discussion of sensory intuition and of sense cognition generally can be found in Rep. III, q. 3, ed. Kelley and Etzkorn (OTh VI), 98-129.

14 Rep. II, qq. 12-13, ed. Gál and Wood (OTh V), 258.13-19: "Nam si naturaliter causetur, tunc non potest esse nisi obiectum exsistat praesens in debita approximatione; quia tanta potest esse distantia inter obiectum et potentiam quod naturaliter non potest potentia tale obiectum intueri. Et quando obiectum est sic praesens tali modo approximatum, potest intellectus per actum assentiendi iudicare rem esse, modo praedicto." ("If [an intuitive cognition] is naturally caused, then it cannot exist unless the object exists and is present in the required proximity. This is because there can be such a distance between 
cognition in turn leads to the formation of and assent to some truth regarding the existence of the object intuited. "Evident assent" or "evident judgment," in Ockham's vocabulary, always refers to some type of knowledge. (In the diagram, I have represented the mental act of judgment-what Ockham often refers to as "assent"- by the judgment stroke.) This same structure applies whether the object in question is external or internal. If the object is external, the intuition in question is a "first-order" act (or what Ockham calls a "direct" act). But if the object of the intuition is itself a mental state, the intuition is a higher-order act (or what Ockham calls a "reflexive" act, since it involves reflexive awareness of one's own states). In either case, however, Ockham supposes that in ordinary circumstances the presence of the object (in relevant proximity to the cognizer) causes an intuitive cognition of it. And just as a first-order intuitive cognition causes a first-order judgment regarding its object (e.g., $\vdash$ 'there exists a rock'), so too a higher-order or reflexive intuitive cognition causes a higher-order judgment regarding its object (e.g.,, 'a perception of a rock exists in me'). ${ }^{15}$ Thus, whereas acts of first-orderintuition ground ordinary perceptual knowledge, higher-order intuition (i.e., consciousness) grounds self-knowledge. ${ }^{16}$

Although Ockham argues at length for the existence of higher-order intuition, he says comparatively little about the type and range of states that can serve as its objects. There are, however, a few places in Ockham's writings that suggest a very wide scope for consciousness. Indeed, in his less cautious moments, Ockham seems even to endorse some kind of self-intimation thesis- going so far as to suggest at one point, for example, that "every act of

the object and the power that the power cannot (naturally) intuit the object. But when the object is present and in such proximity, the intellect can (via an act of assent) judge that the thing exists in the way set out above.")

15 It is not altogether clear why Ockham thinks he is entitled to the self-attributing component of this judgment, since he denies that there can be intuitive cognition of one's own soul. It would seem that the higher-order intuition grounds merely a judgment to the effect that there exists a first-order state, but not the further claim that such a state exists in me. For further discussion of this issue, however, see Sonja Schierbaum's contribution to this volume.

16 Ockham, thus, likewise shares with higher-order perception theorists the view that the distinction between conscious and unconscious states isn't a matter of some difference in their intrinsic nature, but rather a matter of a difference in the relations in which they stand to other states. Ockham himself explicitly says as much in his discussion at Rep. II, q. 17, ed. Gál and Wood (OTh V), 387-389. 
the intellect is evidently known to itself." 17 If this were true-that is, if every act of the intellect were evidently known to it - it would follow that every such act occurs consciously. Needless to say, any such unrestricted commitment to self-intimation would spell serious trouble for Ockham, trouble of just the sort that is often raised against higher-order theories—namely, the threat of infinite regress.

Ockham's arch philosophical rival and fellow Franciscan, Walter Chatton $(\dagger 1343 / 4)$, raises just such a worry for Ockham's account. In fact, he develops several different regress arguments against Ockham's position, all designed to show that Ockham's account entails the "actual" and "simultaneous" occurrence of an infinite number of intuitive states. ${ }^{18}$ Since two of his arguments are especially important for our understanding of the later developments in Ockham's views, I want to consider them here in some detail.19

The first of these two arguments attempts to show that the very same line of reasoning Ockham uses to establish the existence of higher-order intellective intuition can be applied to establish the existence of an infinite series of higher-order intellective intuitions. As Chatton explains:

By the same reasoning [by which you, Ockham, establish that one's state is an object of intuition], I argue that this intuition is seen through another [intuition].... And I argue in the same way with regard to this [further]

17 Ord. Prol. q. 7, ed. Gál and Brown (OTh I), 191.11: "Praeterea, omnis actus intellectus est sibi evidenter notus..." Again, in the context of arguing for the liberty of indifference in the will, Ockham claims that it is possible to know, just by introspection, whether acts of volition are (or are not) influenced by other mental states. See Quodl. I, q. 16, ed. Wey (OTh IX), 88. Such a claim suggests a very broad scope for self-knowledge indeed-one that extends not only to all occurrent acts of thinking or willing, but perhaps even to dispositional states as well. After all, if one can know via introspection that her will is utterly unconstrained by any other mental state (e.g., beliefs, sensory appetites, etc.), it would seem she must be aware both of what mental states are present in her at the moment of willing and of the nature of their influence on her will.

18 Chatton devotes an entire section of his own treatment of intuitive cognition to the question of whether there can be higher-order intuitive states. He considers this in a. 5 of q. 2 in the Prologue to his Sentences commentary. See Walter Chatton, Reportatio et Lectura super Sententias: Collatio ad Librum Primum et Prologus, ed. J. Wey (Toronto, 1989).

19 I consider a third such argument in 'Medieval Approaches to Consciousness', 21-23. 
act, and so on to infinity. [...] [That it goes to infinity] is confirmed, since one will equally be able to acquire knowledge by experiencing that vision, and equally [acquire knowledge of that experience] from a vision of that vision. In this way, I apply to infinity precisely what you suppose with regard to the direct act. Therefore, you prove equally that there are an infinite number of visions. I confirm this, since Augustine would equally suppose that, just as I see my faith, I see that vision of my faith, and this because he would equally suppose that I cognize it [namely, the vision of my faith] with certainty. ${ }^{20}$

The basic line of argument here is straightforward. Just as Ockham appeals to second-order intellective intuition to account for knowledge of first-order states, so also, Chatton suggests, it is necessary for him to appeal to a thirdorder intuition to account for knowledge of second-order states, and so on. Of course, the argument rests on the assumption that the domain of selfknowledge extends to all occurrent states (an assumption Chatton attempts to bolster in this passage by citing the authority of Augustine). We've already seen that there are some grounds for supposing that such a view about the scope of self-knowledge held some attraction for Ockham. Even so, in his more careful moments - that is, when responding to just these sorts of objectionsOckham foregoes any commitment to ubiquity or self-intimation.

If Ockham really does mean to restrict self-knowledge primarily to firstorder states, then he has a way around Chatton's first regress argument. Even so, Chatton's second regress argument is designed to show that Ockham has no principled basis for restricting self-knowledge in this way. In particular, Chatton claims that, given Ockham's own account of the nature of intuitive cognition, the occurrence of a single conscious state requires an infinity of them. To appreciate the force of this second regress argument, we need only note that in general Ockham holds that the mere presence or proximity of an object to a cognizer is, in ordinary circumstances, sufficient to give rise to intuitive cognition of it. ${ }^{21}$ But if this is true in general, then the same principle

20 Walter Chatton, Reportatio, Prol. q. 2, a. 5, ed. Wey, 119. 32, 35-42: "Per eandem rationem arguo quod illa intuitiva videtur per aliam [...] Ita arguo de illa, et sic in infinitum [...] Confirmo, quia aeque poteris acquirere scientiam per experientiam de illa visione, et aeque de visione illius visionis; et sic arguo de infinitis sicut tu ponis de actu recto; igitur aeque probas infinitas. Confirmo, quia Augustinus aeque poneret me videre visionem fidei meae sicut quod videam meam fidem, quia aeque poneret quod certitudinaliter cognoscitur."

21 See, for example, M.M. Adams, William Ockham (Notre Dame, 1987), 510-511. See also note 24 below. 
would seem to apply in the case of higher-order intuitive cognition: the presence of an occurrent first-order state should be sufficient for the production of a second-order intuitive cognition of it. By parity of reasoning, the occurrence of the second-order state should be sufficient for producing a third-order cognition. And so on ad infinitum.

Chatton's own formulation of the argument runs as follows:

There is no avoiding that infinite numbers are necessarily caused. If you [claim to] experience an end point at the second[-order] vision, I ask: on what basis does the end point come at the second? If you say that it is because that vision is not visible by such a power [namely, the intellect], I say this is false. [...] For, from the fact that it exists in the intellect it is not to be denied that it can be seen by it. After all, on your view, the thought of the rock is in the intellect, and yet it is seen by it. Therefore, it is not to be granted that the [second-order] vision of it is not, on your view, visible to the intellect. [...] Therefore, I argue as follows: the thought of a rock and the vision of that thought are necessarily equally visible to the intellect in which they exist. And the [intellective] power is equally disposed with respect to each, and each is received equally immediately in the power. Thus, if your experience is that thinking of the rock necessarily causes a vision of it, you equally experience this with respect to the vision [of that thought], no matter what you say. ${ }^{22}$

In developing this second regress argument Chatton makes two important assumptions. First, he assumes that all (occurrent) mental states are, in themselves, equally present or, as he puts it here, "equally visible" to the cognizer in whom they occur. Thus, to take his example, the first-order "thought" of a rock and the second-order perception (or "vision") of it are "equally visible" to the intellect. And this, he explains, is because they are equally disposed to act on the intellect to produce an act of higher-order intuitive cognition; and the

22 Walter Chatton, Reportatio, Prol. q. 2, a. 5, ed. Wey, 120.6o-62, 65-68, 74-78: “Tertio, non vitas quin necessario causarentur infinitae, quia si experiris statum in secundo, quaero propter quid est status in secundo. Si dicis quod quia illa visio non est visibilis a tali potentia, hoc est falsum [...] quia per hoc quod est in intellectu, non tollitur quin possit videri, quia per te intellectio lapidis est in intellectu, et tamen videtur ab eo; igitur non est dandum quod quia illa visio non est visibilis ab illo intellecto per viam tuam. [...] Arguo igitur sic: intellectio lapidis et visio illius intellectionis aeque necessario sunt visibiles ab intellectu in quo sunt, et potentia est aeque disposita respectu utriusque, et utraque aeque immediate recipitur in potentia; igitur si experiris quod intellectio lapidis necessario causet visionem sui, aeque experiris hoc de illa visione, quidquid dicatur verbotenus." 
intellect is likewise equally disposed to being so acted on by each. The second assumption is this: if two or more things are equally visible to a cognizer, then the conditions that suffice for the one's producing an act of intuitive cognition suffice for the other's doing so.

Drawing on these assumptions, we can state Chatton's second regress argument as follows:

1. All of one's (occurrent) mental states are equally present-i.e., equally visible - to the intellect.

2. If two (or more) things are equally present to a cognitive power, then whatever conditions suffice for intuitive cognition of the one will likewise suffice for intuitive cognition of the other.

3. In ordinary conditions, the mere presence of a given occurrent mental state is sufficient to cause (higher-order) intuitive cognition of it.

4. Hence, in ordinary conditions, intuitive cognition of a single state will generate an infinite number of increasingly higher-order intuitive cognitions.

Chatton takes for granted, rightly I think, that Ockham would accept each of his two assumptions. It's fair to say, therefore, that Ockham is committed to the first two premises of the argument as I've reconstructed it. Ockham has no reason to reject the first premise, and the second is just the direct application of one of his own causal principles to the specific case of intuitive cognition. ${ }^{23}$ Again, Chatton has good reason to think Ockham is committed to the claim represented in the third premise. After all, this claim seems to follow from Ockham's own contention that, in cases of ordinary perception, the presence (i.e., existence and adequate proximity) of an object is sufficient for an intuitive cognition of it. ${ }^{24}$ But, obviously, if Ockham is committed to all three premises, Chatton has his regress.

23 The more general causal principle, as Ockham states it, is this: "Things of the same kind that are equally perfect can have effects of the same kind on the same patient when it is equally disposed [to receive this effect from each]." Ord. Prol. q. 1, a. 1, ed. Gál and Brown (OTh I), 22.3-23.1 (“... illa quae sunt eiusdem rationis et aeque perfecta possunt in eodem passo aequaliter disposito habere effectus eiusdem rationis ...").

24 This is a claim Ockham makes explicitly for first-order intuitions-even in his earliest writings. Thus, in Rep. II. qq. 12-13, in the context of arguing against the necessity of postulating species as a cause or principle of cognition, Ockham argues that the object itself (in sufficient proximity to the intellect) is sufficient for cognition. He reiterates the same basic point in a number of other contexts as well. For example in $Q V$ q. 5 he claims, "an object can cause some cognition through itself" (ed. Etzkorn, Kelley, and Wey [OTh VIII], 
While the argument isn't decisive, it certainly exercises Ockham more than the first. In particular, as Ockham himself recognizes, it requires him, at the very least, to provide some principled basis for restricting the range of states that can serve as objects for higher-order intuition. In responding, Ockham focuses on the claim made in the third premise-namely, the claim that the mere occurrence of a mental state is sufficient for intuition of it. As we shall see, his initial impulse is simply to deny this claim on the grounds that perception is not a wholly passive process and, hence, that the mere occurrence of a given state does not suffice for higher-order perception of it. In later discussions of the regress argument, however, he returns to the passive view of perception, but introduces a qualification to allow for impediments to the (passive) production of intuitive states. He then argues that, in the case of higher-order intuitive states, such an impediment is almost always present.

In nearly every context in which Ockham discusses higher-order intuition he also considers associated worries about infinite regress. Although it is only in later works that Ockham specifically addresses Chatton's particular formulations of the regress objection, similar worries arise even in Ockham's earliest writings. I begin therefore by considering his early treatments of the regress objection. I then turn to his treatment of the same issue in later writingswritings in which he responds specifically to Chatton's version of the regress argument.

\subsection{Response to the Threat of Infinite Regress I: Ockham's Earlier Writings}

To my knowledge, Ockham's earliest treatment (ca.1318) of the regress objection to higher-order intuition occurs in question 5 of his Quaestiones Variae. ${ }^{25}$ The focus of his discussion in this context isn't the issue of higher-order intuition

181.525-526: "Et ista volitio ... causat cognitionem perfectiorem quam causaret obiectum per se...") and elsewhere he insists likewise: "the efficient cause of the intuitive cognition is the cognized thing itself." Ord. Prol. q. 1, a. 6, ad 3, ed. Gál and Brown (OTh I), 61.9-10: “... quia causa effectiva notitiae intuitivae est ipsa res nota...” Cf., Ord. Prol. q. 1, a. 6, ed. Gál and Brown (OTh I), 54, and Reportatio. Quaestiones in librum quartum Sententiarum, q. 14, ed. R. Wood and G. Gál, with R. Green (OTh VII), 286.10-15.

25 Ockham's Questiones Variae date roughly to the time Ockham was composing his Reportatio II-IV. For fuller discussion of their dating in relation to Ockham's other writings, see the introduction to OTh VIII. 
per se, but rather a question about the passivity of the intellect in cognition. And here, in opposition to nearly all of his contemporaries, Ockham attempts to defend the claim that the intellect's role in cognition can be regarded as wholly passive. ${ }^{26}$ In the course of defending this position, however, Ockham considers an objection that is, in essence, a variant of Chatton's second regress argument. The objection, as it is framed here, takes its start from the observation that if the intellect is passive and, hence, causally inert in the production of higher-order states, then the cause of acts of reflexive awareness must be the mental states they target. In that case, however, the mere occurrence of a given mental state will be causally sufficient for higher-order awareness of it. But this, of course, leads to an infinite regress in higher-order states. ${ }^{27}$

In reply, Ockham has the following to say:

I say that a reflexive act is caused by the direct act as [its] object and by an act of will—namely, one by which one wills that the act be intellectively cognized. That it is [partly] caused by the direct act is clear, since the reflexive act depends necessarily on the direct act, and cannot be caused without the direct act's existing. Hence, it depends on [the direct act] as some kind of cause and, clearly, only as an efficient cause. That an act of will is [also] required is obvious, since someone can think about something and, nevertheless, not perceive that he is thinking about it. In the same way, someone can see and not perceive that he sees. But if a reflexive act were caused just by the intellect and the direct act, then as soon as the direct act is introduced and so long as it persists, the intellect would immediately and necessarily perceive that it thinks. But this is manifestly contrary to experience. Therefore, an act of will is required (namely, one by which one wills that that [first-order] act be cognized). [...] And so it is clear that it is not necessary to introduce an infinite regress, since the

26 Though, oddly, at the end of his lengthy defense of this position, Ockham refuses actually to endorse the view.

27 QV q. 5, ed. Etzkorn, Kelley, and Wey (OTh VIII), 159-160.79-83: "Praeterea, actus reflexus non causatur ab actu recto vel obiecto actus recti. Quia si sic, cum sint causae naturales, pari ratione causabunt actum reflexum super illum actum et sic in infinitum. Et sic non posset causari unus actus reflexus nisi causarentur infiniti, quod falsum est. Igitur causantur ab intellectu." ("A reflexive act is not caused by a direct act or by the object of a direct act. After all, if it were so caused, then, insofar as these are natural causes, by parity of reasoning they would cause [a further] act, one that is reflexive on that [preceding reflexive] act, and so on to infinity. And, hence, one reflexive act could not be caused unless an infinity of them were caused, which is false. Therefore, they are caused by the intellect.") 
will can will that one act of the intellect be cognized without its willing that another act of the intellect be cognized. ${ }^{28}$

The first thing to note about Ockham's response in this passage is that he expressly rejects the claim that mental states are self-intimating and, hence, that consciousness is ubiquitous. Such a view is, he says here, "manifestly contrary to experience." After all, "one can see and, nevertheless, not perceive that he sees." In order to justify this claim, Ockham argues that the mere occurrence of a mental state is not sufficient to produce a higher-order cognition of it. Something further is required: namely, an act of will on the part of the cognizer in directing attention to that first-order state. Accordingly, higher-order perception (and, hence, consciousness) extends only to those states to which one choses to attend. But since "the will can will that one act of the intellect be cognized without its willing that another act of the intellect be cognized," there is, Ockham concludes, no worry about regress.

By introducing will as a necessary condition for consciousness, Ockham offers a principled basis for limiting the range of consciousness and, thus, a reply to the regress objection. Even so, there is little else to recommend the view. For starters, the view is phenomenologically implausible. Even if we concede that ordinary experience supports Ockham's contention that we are not always aware of all our occurrent states, it does not support his further claim about the role will plays in explaining this fact. After all, consciousness of our states very often seems to occur without any apparent effort on our partwithout any act of will or express attention. Indeed, in general, my awareness of my current perceptions, desires, etc. seems more like something that happens to me than something that I do or will. This is not to deny that we can, and perhaps even regularly do, exercise some control over what we are conscious of at a given moment. I can, for example, actively choose to turn my

28 QV q. 5, ed. Etzkorn, Kelley, and Wey (OTh VIII), 177-178.449-466. "Ideo dico quod actus reflexus causatur ab actu recto tanquam ab obiecto et ab actu voluntatis quo vult illum actum intelligi. Quod autem causetur ab actu recto patet, quia actus reflexus necessario dependet ab actu recto quia non potest causari nisi exsistente actu recto. Igitur in aliquo genere causae dependet, et patet quod nonnisi sicut ab efficiente. Quod autem actus voluntatis requiritur patet, quia aliquis potest aliquid intelligere et tamen non percipere se intelligere, sicut potest aliquis videre et tamen non percipere se videre. Sed si actus reflexus causaretur praecise ab intellectu et actu recto, statim posito et stante actu recto, intellectus necessario statim perciperet se intelligere quod est manifeste contra experientiam. Igitur requitur actus voluntatis quo vult illum actum cognosci. [...] Et sic patet quod non oportet ponere processum in infinitum, quia potest voluntas velle unum actum intellectus cognosci absque hoc quod velit alium cognosci." 
attention away from one thing (e.g., the news program on the car radio) and to something else (e.g., the kids singing in the back seat). Even so, it's implausible to suppose that consciousness is like this in general-that is, that consciousness always requires some positive contribution on the part of the will or one's actively directing one's attention. ${ }^{29}$

Aside from these sorts of phenomenological considerations, there are further problems for the view. Ockham wants to claim that consciousness of a given first-order state depends on an act of will directing one's attention to that state. But how can we direct our attention to a state we are not (yet) conscious of? It is particularly difficult to see how Ockham himself can answer this question, given his own contention that every act of volition presupposes an act of cognition with respect to its object. As he says, "nothing is loved unless it is first cognized."30 Indeed, on his view, the act of cognizing some object (or perhaps cognizing it in a certain way) is itself an efficient cause of subsequent acts of will involving it. ${ }^{31}$ But these claims about the causal dependency of will on cognition appear to undermine Ockham's insistence on the causal dependency of acts of higher-order intuition on voluntary attention. Indeed, taken together these various claims about the dependence relations among mental states appear to land Ockham in a vicious explanatory circle. On the one hand, Ockham appeals to acts of will in explaining the occurrence of higher-order acts of intuitive cognition. He insists that it is only by willing to attend to a given first-order state that one can reflexively cognize (and hence come to be conscious of) it. On the other hand, he claims that all acts of will depend for their production on (logically) prior acts of cognition with respect to their object. Hence, willing to attend to a given first-order state requires a prior cognition of that state. But such a cognition cannot exist unless one has already willed to attend to that same first-order state. ${ }^{32}$

Perhaps Ockham has at his disposal the resources to answer this worry about explanatory circularity. The problem, as I've just developed it, depends on the assumption that higher-order awareness of a given state requires an act of willing to attend to that state in particular. It may be, however, that all that's

29 Indeed, choosing to shift attention from one thing to another seems less a transition from non-consciousness to consciousness than a transition involving bringing something at the periphery of consciousness to the center.

QV q. 5, ed. Etzkorn, Kelley, and Wey (OTh VIII), 178.477: “... nihil est amatum nisi cognitum..."

31 Rep. II, q. 20, ed. Gál and Wood (OTh V), 441.

32 Pasnau gestures at this (or, in any case, a very similar) worry in connection with Ockham's discussion of the role of will in cognitive attention. See R. Pasnau, Theories of Cognition in the Later Middle Ages (Cambridge, 1997), 155. 
really required is a generic volition - that is, a volition to attend to (first-order) states of a given type. For example, a subject could choose to turn her attention to her current visual states (whatever they may be); or, she could decide to think about what happened yesterday (whatever that may be) without, thereby, willing to attend to any particular memory content. Such generic acts of willing wouldn't depend on prior cognition of any particular mental state. Rather, insofar as their content is purely general or descriptive in nature, they would involve merely the possession of the relevant general concepts (i.e., concepts such as 'seeing' or 'memory'). Such a move might still allow Ockham to appeal to the role of will to block the regress, and yet to do so without thereby falling prey to explanatory circularity.

That Ockham might even have had such a move in mind is suggested by an example he considers a bit later in the same discussion, namely, of how one can come to possess a higher-order desire. In this context, the particular example he considers is a case of a second-order love.

When someone loves [something], it is not required that he perceive that he loves [it]. However, in cases where the will wills its own act to be cognized, the second, [higher-order] volition is immediately caused by [the occurrence of three things, namely]: [a] by the will [wanting to attend to its states], [b] by the initial [i.e., first-order] volition, and [c] by the [firstorder] cognition by which the loved object is cognized. And with these three posited, immediately without any activity of the intellect another act of cognition occurs naturally, namely [d] one by which the first-order act of loving is cognized. ${ }^{33}$

According to Ockham, the occurrence of the higher-order desire (in his case, an act of loving love) presupposes the following: an initial first-order cognition of some object (this answers to item [c] on Ockham's list), a first-order act of loving or desiring it (this is [b]), and, finally, a general higher-order desire to attend to one's (first-order) desires (this is [a]). The occurrence of these three things is, he says, sufficient for immediately causing higher-order awareness of the first-order desire (this is item [d]). And this, in turn, is sufficient for the

33 QV q. 5, ed. Etzkorn, Kelley, and Wey (OTh VIII), 179.481-487: "Et ita quando aliquis amat, non oportet quod percipiat se amare, sed statim quando voluntas vult actum suum cognosci, secunda volitio causatur a voluntate et a prima volitione et cognitione qua cognoscitur obiectum amatum. Et istis positis, statim sine omni activitate intellectus, sequitur naturaliter unus alius actus cognitionis quo cognoscitur primus actus amandi." 
forming of a particular higher-order desire-namely, one relating to the firstorder act of love.

Although the introduction of a general act of will would seem to help with the worry about circularity, it does not—-so far as I can see-mitigate the phenomenological implausibility of assigning will an essential role in consciousness. (As we noted earlier, in many cases, conscious experience occurs with no contribution from the will whatsoever.) Nor is its introduction sufficient to explain all the phenomena at issue. Ockham seems to think that the appeal to acts of volition can explain not only the restriction of consciousness to firstorder states, but also its restriction to a given subset of these. It's not clear, however, that a generic desire or act of will can explain this latter restriction. Whereas the formation of a general volition, say, to attend to my auditory perceptions can explain why I'm conscious of hearing anything at all (and also why I'm conscious only of my first-order state-namely, hearing - and not of my second-order state, namely of my awareness of hearing), it is not clear that this same volition can explain why I'm conscious of one set of auditory inputs (say, the news story on the car radio) rather than others (say, the kids' singing in the back seat). To explain the specific contents of consciousness, a more fine-grained act of attention (and, hence, volition) would seem to be required - and yet, as we have just seen, it is precisely these more fine-grained acts of will that lead to the circularity problem. It appears, then, that the will cannot play all the explanatory roles that Ockham wants to assign it.

To my knowledge, Ockham never explicitly considers or addresses these latter sorts of worries for his account of the role of will in attention and consciousness. Even so, they may help explain why, in subsequent treatments of the regress objection, Ockham's response takes a rather different form. In any case, in his later writings, when Ockham returns to the regress objectionand, specifically to Chatton's various formulations of it-he abandons this early contention that will plays an essential role in consciousness.

3.2 Response to the Threat of Infinite Regress II: Ockham's Later Writings There are two places in Ockham's later writings in which he specifically undertakes to respond to Chatton's objections to his account of higher-order intuition. ${ }^{34}$ As in the case of his earlier discussion, in each of these contexts

34 See Ord. Prol. q. 1, a. 6, ad 4, ed. Gál and Brown (OTh I), 65, and Quodl. I, q. 14, ed. Wey. The Quodlibet discussion is essentially a sustained response to Chatton's various objections to higher-order intellective intuition. Interpreting the discussion in $\mathrm{Ord}$. as a response to Chatton is more controversial. Yet, the fact that Ockham replies specifically to the very sort of objection Chatton raises (and one framed in terms very like Chatton's own) 
Ockham denies that consciousness is ubiquitous. In fact, he suggests that consciousness (and, hence, self-knowledge) does not—at least in general—extend beyond our first-order states. Thus while, in the ordinary course of things, our first-order states are conscious, our second-order states typically are not. For the same reason, he suggests, any regress in higher-order states will (typically) stop at the second-order level:

The regress will stop at a vision that will not naturally be seen by means of a distinct vision-even though it could be seen if there were no impediment. I grant that the regress [could go on] ad infinitum by the divine power. However, speaking naturally, there will be some vision that cannot be seen. This is because our intellect is a limited power and thus capable of a set number of visions and no more. I do not know, however, at which vision [the regress] is stopped - though perhaps it is stopped at the second-order vision, since the second-order vision may not be seen naturally. 35

Interestingly, when Ockham responds to Chatton's regress this time, the rationale he offers for restricting the scope of consciousness makes no appeal to the role of the will in directing attention. Instead, his rationale now has to do with certain "limitations of the intellect" - in particular, a limitation on the scope of its capacity for conscious attention. We are, Ockham claims, "capable of a set number of acts of vision and no more." Such limitations, he maintains, function as an "impediment" to the production of higher-order states. Indeed, Ockham blocks the regress precisely by claiming that the presence of secondorder intuition of a given first-order state will ordinarily impede any intuition of the second-order state itself.

Thus, as with his earlier reply to the regress objection, Ockham's response focuses on the sufficiency claim at work in the third premise of Chatton's (second) regress argument, namely, the claim that the mere occurrence of a

suggests that Ockham was aware of and responding to Chatton's objections when he was preparing the Ordinatio version of his Sentences commentary. In any case, Ockham's response is much the same as that given in Quodl. I, q. 14.

35 Quodl. I, q. 14, ed. Wey (OTh IX), 80.32-40: “... tandem stabitur ad aliquam visionem quae non videbitur distincta visione naturaliter, quamvis possit videri si non esset impedimentum. Et concedo processum in infinitum per potentiam divinam. Sed naturaliter loquendo, erit aliqua visio quae non potest videri; et hoc quia intellectus noster est potentia limitata, ideo potest in certum numerum visionum et non in maiorem. Sed in qua visione est status nescio. Forte tamen status est in secunda visione, quia ipse forte non potest naturaliter videri." 
first-order state will be sufficient for reflexive awareness of it. As the foregoing indicates, however, what Ockham has to say about the sufficiency claim this time around is importantly different. Whereas Ockham initially rejects this claim in favor of a view according to which cognizers play an active role in perception and consciousness, he now returns to the more passive conception of cognition, preferring instead to introduce an important (and plausible) qualification on the sufficiency claim. Thus, Ockham grants that the presence of a first-order state is sufficient to produce higher-order intuitive cognitionprovided there are no impediments to its production. But, according to Ockham, there almost always is such an impediment. The impediment, he argues, owes to the noetic limits of the human mind itself. Just how much of an impediment such cognitive finitude presents will vary depending on the different cognitive capacities of different individuals. But ordinarily (or at least in his experience of his own states) Ockham thinks the presence of even a single higher-order mental state will be sufficient to block the production of any further such states:

I grant that if there were a second vision in the soul, then it would be able to be seen if there were no impediment. But if the second vision existed in my soul along with the first, then I would not be able to see it, since the first act prevents the second vision from being seen. And I claim that it is not because the second vision exists in the intellect that the possibility of its being seen is removed, since if it existed by itself in the intellect then it would be able to be seen. Rather, it is because it exists in the intellect along with the other act that the possibility of its being seen is removed. And I claim that I experience the vision of the rock, but that I do not experience the vision of that vision. In support of this reply there is Augustine's example in De Trinitate XI, at the end of chapter 8 , where he says that oftentimes he has read [aloud] and yet not known what he has read or heard because he was distracted by the act of another faculty—even though there was no incompatibility between the acts in question. So too it frequently happens that a person who is intent on seeing does not perceive that he is hearing something even though he is hearing it. [...] This is how it is in the case under discussion. ${ }^{36}$

36 Quodl. I, q. 14, ed. Wey (OTh IX), 81.57-72: “... concedo quod si esset in anima secunda visio, quod posset videri nisi esset impedimentum; et tamen si esset in anima mea cum prima visione, non possem videre, quia primus actus impedit secundam visionem videri. Et dico quod per hoc quod est in intellectu non tollitur quin possit videri, quia si esset in intellectu per se, posset videri; sed per hoc quod est in intellectu simul cum alio actu 
Thus, if we return to (my reconstruction of) Chatton's second regress argument, we can see exactly how Ockham's response is supposed to work. The argument, again, runs as follows:

1. All of one's (occurrent) mental states are equally present-i.e., equally visible - to the intellect.

2. If two (or more) things are equally present to a cognitive power, then whatever conditions suffice for intuitive cognition of the one will likewise suffice for intuitive cognition of the other.

3. In ordinary conditions, the mere presence of a given occurrent mental state is sufficient to cause (higher-order) intuitive cognition of it.

4. Hence, in ordinary conditions, intuitive cognition of a single state will generate an infinite number of increasingly higher-order intuitive cognitions.

As we've seen, Ockham agrees with the first and second premises. He also now accepts a suitably qualified version of the third. Hence, we can think of him as rejecting premise 3 in favor of

$3^{*}$. In ordinary conditions, the mere presence of a given occurrent mental state is sufficient to cause (higher-order) intuitive cognition of itprovided there is no impediment.

In this way, Ockham can agree with Chatton in supposing that the first-order and second-order acts are equally visible to the intellect and that conditions sufficient for the production of both types of cognition are the same. He can even allow that, in principle (that is, absent any impediment), the mere presence of an object or a state is sufficient for intuitive cognition of it. But when multiple acts occur simultaneously in a finite intellect there will, in fact, be an impediment to higher-order intuition of them and, hence, only a subset will be available to consciousness. And this, Ockham tells us, is because the limitations of the intellect's cognitive capacity are such that second-order cognition of a given first-order act impedes the simultaneous production of intuitive cognition of the second-order state. If such acts did not occur at the same time

tollitur quod non potest videri. Et dico quod experior visionem lapidis, sed visionem illius visionis non experior. Pro ista responsione est exemplum Augustini, XI De Trinitate, c. 8 in fine, ubi dicit quod saepe legit et tamen nescivit quid legit vel audivit propter distractionem per actum alterius potentiae; et tamen inter illos actus nulla est repugnantia. Sic etiam frequenter homo intentus ad videndum nihil percipit se audire cum tamen audiat [...] Ita est in proposito ..." (correcting Wey's punctuation). 
(or if the intellect were unlimited, and so able to divide attention), the secondorder act would, in fact, be cognized — and, so, would occur consciously.

Ockham is quick to point out, moreover, that his claim about consciousness of one state impeding consciousness of another has excellent Augustinian credentials. Famously, Augustine argues in De Trinitate XI that one can fail to be conscious of some perceptual state occurring in us at a given moment due to one's being preoccupied with some other thought. Although Augustine himself isn't concerned with the simultaneous occurrence of first- and secondorder states, Ockham takes the principle behind Augustine's example to be perfectly generalizable: conscious awareness of one mental act or state can and actually does obstruct or impede our capacity for consciousness of other, co-occurrent states.

Drawing on the Augustinian claim about the limits of consciousness, Ockham is thus able to block the regress argument and likewise the charge that his view leads to absurdity. As should be clear, moreover, this same line of response justifies not only his restriction of consciousness primarily to occurrent first-order states, but also its further restriction to just a subset of these. Notice that in the foregoing passage, in an attempt to illustrate the Augustinian claim, Ockham says, "it frequently happens that a person who is intent on seeing does not perceive that he is hearing something even though he is hearing it." What this remark makes clear is that, on Ockham's view, consciousness of a given first-order state can impede not only our conscious access to occurrent higher-order states, but even access to other occurrent first-order states. In the case Ockham cites, conscious first-order visual perception impedes consciousness of an occurrent act of first-order auditory perception.

This view about the intellect's finite cognitive capacity combined with the claim that the multiple acts can occur simultaneously in the intellect (a claim that was controversial in Ockham's day, but which he explicitly defends $)^{37}$ gives Ockham a principled account of the limits and scope of consciousness. Thus, Ockham concludes:

And this [inability to experience infinite visions] is because of the limitation of the intellect, which is capable of just so many visions and no more. I grant, however, that one can naturally have more than one vision-at least two or three- of the same object at the same time. ${ }^{38}$

37 See, e.g., Ord. Prol. q. 1, a. 1, ed. Gál and Brown (OTh I), 17-19.

38 Quodl. I, q. 14, ed. Wey (OTh IX), 80.44-47: “... et hoc propter limitationem intellectus qui potest in tot visiones et non in plures. Concedo tamen quod potest naturaliter habere plures visiones simul, saltem duas vel tres, eiusdem obiecti." 
Thus, while at a given time there may be any number of states occurrent in the intellect (though here too there will, no doubt, be some natural cognitive limitations), consciousness extends only to a limited set of them. Indeed, on Ockham's account, we are typically conscious of only one such state at a timeor possibly more if the acts in question involve one and the same object. We might, for example, have multiple conscious acts (e.g., seeing, smelling, tasting) with regard to a given object. Or, again, we might introspect our conscious act of seeing a given object (Ockham thinks that higher-order acts have as indirect objects the object of the lower-order states they target).

Yet even if, in his later writings, Ockham no longer takes acts of volition as necessary for consciousness, there is no reason to suppose that he regards will as playing no role in consciousness. In fact, there's good reason to think just the opposite is the case: namely, that he still allows a fairly significant role for will. For, while Ockham rejects any unrestricted thesis about mental states being self-intimating, he appears, nevertheless, to endorse a more qualified version of such a thesis. Even if the mere occurrence of a given first-order state doesn't, on Ockham's view, entail knowledge or awareness of it, its occurrence does entail the possibility of such knowledge or awareness. As he says at one point: "if I cognize something (in whatever way I do) I can know that I am thinking of this thing." ${ }^{39}$ Hence, while not all of the states occurrent in a given subject at a given moment are actually known to her, they are, nonetheless, accessible to her. Ockham's idea, I take it, is that a subject can shift or redirect awareness from whatever happens to occupy her consciousness at a given moment and instead attend to something else. A subject can, in other words, exercise some control over which among her mental states occurs consciously and, hence, which are known by her. If this is right, however, it's clear that will plays an important-if more restricted-role in Ockham's account of consciousness. Of course, whether even this more restricted role can be defended, given Ockham's other commitments, remains unclear. We still need an account of how one can turn attention to states of which one is currently unaware. But, for reasons highlighted already, Ockham has some difficulty explaining just this sort of phenomenon. ${ }^{40}$

39 Ord. Prol. q. 1, a. 6, ad 4, ed. Gál and Brown (OTh I), 65.22-23: "Quia si cognosco aliquam rem qualitercumque, possum scire me intelligere illam rem."

40 What Ockham needs is some notion of peripheral awareness, perhaps something along the lines of what Scotus appeals to in his own account of the role of will in thought. Scotus, like Ockham, thinks that one can have multiple acts of cognition simultaneously. Unlike Ockham, however, he allows that we can be dimly aware of some acts and focally aware of another. Thus, he claims: "For every single perfect and distinct intellection exist- 


\section{Conclusion}

Whether or not Ockham is ultimately successful in explaining the role of will in consciousness, it should be clear that the line of response that he adopts in his most mature writings to the regress objection represents both a development and an improvement in his thinking. His mature account is far more satisfying — phenomenologically and philosophically — than his earlier line. Indeed, the account that emerges from his later texts accommodates both the fact that, ordinarily, we are conscious only of our first-order states and that, more often than not, only a select few of these register at the level of conscious awareness. What is more, unlike his earlier account, his claims about limited scope of consciousness rest not on a controversial claim about the essential role of will in consciousness, but rather on a far more plausible claim about the limited capacity of the human mind.

\section{Acknowledgment}

The author presented an early version of this article at the 2011 Cornell Colloquium in Medieval Philosophy. She is grateful for discussion and feedback from audience members on that occasion. The author would also like to thank Jeffery Brower for his helpful comments on the article.

ing in the intellect there can be many indistinct and imperfect intellections existing there. This is evident from the example of vision, the field of which extends as a conical pyramid at the lower base of which one point is seen distinctly, and yet within that same base many things are seen imperfectly and indistinctly; but of these several visions, only one is perfect, namely that upon which the axis of the pyramid falls. If this is possible in one of the senses, all the more is it possible in the intellect." Ord. II, d. 42, qq. 1-4, n. 10, trans. A. Wolter in Duns Scotus on the Will and Morality (Washington, D.C., 1987), 150. Although Ockham does recognize the possibility of one's giving a greater or lesser degree of attention to a single object (see $Q V$ q. 5, ed. Etzkorn, Kelley, and Wey [OTh VIII], 180-184), I know of no place where he expressly acknowledges the possibility of peripheral awareness of multiple objects. But perhaps something akin to such a phenomenon would accompany a general volition to attend one's first-order states. That is to say, perhaps in such a case one might be dimly or peripherally aware of multiple states without attending to any one of them in particular. 